\title{
IMPLEMENTING TASK-BASED LANGUAGE TEACHING TO OVERCOME THE PROBLEMS OF TEACHING SPEAKING
}

\author{
Suswati Hendriani \\ Program Studi Tadris Bahasa Inggris, Jurusan Tarbiyah STAIN Batusangkar \\ Korespondensi: Perumahan Arai Pinang I Blok i No.6 Kuburajo, Lima Kaum, \\ Batusangkar, Sumatera Barat \\ e-mail: suswatiamor@gmail.com
}

\begin{abstract}
Teaching students to speak English is not an easy task. The teachers shoud consider and think hard about several points to be done: to make the students motivated to speak English, to keepthem speaking the new language, and to make them have accuracy in speaking the language, and to correct the students' mistakes without feeling being blamed or discouraged. To handle the difficult tasks previously mentioned, the English teachers should find a solution. Teaching the students through unforgettable, interesting experiences might be one of the solutions that they can choose. Therefore, teaching speaking might be best done through task-based instruction.
\end{abstract}

Kata kunci: teaching, speaking

\section{INTRODUCTION}

Deaching students to speak English is not an easy task. The teachers shoud consider and think hard about several points to be done. First, they should make the students motivated to speak English. There are, in fact, many students who do not eager to speak English just because they do not like to learn English. To get them to become motivated to speak the new language, of course, will be a very difficult task for the teachers. If the students have been motivated, the next task is waiting: the teachers should make the students keep speaking the new language. To make the students speak English with the frequency as expected will be the next challenging task for the English teachers since there are some students who feel shy and do not have self-confidence to speak
English, feel afraid of making mistakes, and face many other discouriging habits. If the students keep talking English already, the next task is making them get accuracy in speaking the language. Correcting the students' mistakes without the students' feeling blamed or discouraged is another difficult task that the teachers should face. To handle the difficult tasks previously mentioned, the English teachers should find a solution. Teaching the students through unforgettable, interesting experiences might be one of the solutions that they can choose. Therefore, teaching speaking might be best done through task-based teaching or instruction.

Considering the previous problems, the language activities and/tasks to be performed by the students seem very influential. This paper, therefore, discusses task- 
basedteaching as a technique to overcome the problems of teaching speaking.

\section{CHARACTERISTICS OF TASK- BASEDLANGUAGE TEACHING}

Before the technique (or the approach) is discussed, it is advantageous to look at the characteristics of it at a glance. Nunan (1991a) proposes five characteristics of a task-based approach (and of course the techniques its derived) to language teaching. The characteristics are: 1) It gives an emphasis on learning to communicate through interaction in the target language, 2) It introduces authentic texts into the learning situation, 3) It provides opportunities for learners to focus, not only on language, but also on the learning process itself, 4) It enhances the learner's own personal experiences as important contributing elements to classroom learning, and (5) It attempts to link classroom language learning with language activation outside the classroom.

\section{ADVANTAGES OF TASK-BASED TEACHING}

According to Ur (1996), advantages of task-basedteaching language learning over other approaches are that students are likely to be more motivated if they see an activity as meaningful and as having some relevance to authentic activities which they may be called on to perform outside class. Moreover, according to Harmer (200?: 71-72) the task-based teaching "makes the performance of meaningful tasks central to the learning process...if students are focused on the completion of a task, they are just as likely to learn language as they are focusing on language forms."
Then, Thornbury (1999: 134) states that by offering learners an opportunity to make meanings for themselves, task-based approach seems to replicate more closely natural acquisition approaches.

Ur (1996, 124) emphasizes the task-centered activity for there is more talk, more even participation, more motivation and enjoyment.

\section{HOW DOES TASK-BASED LANGUAGE TEACHING OVERCOME THE PROBLEMS OF SPEAKING?}

Let's start our discussion with what Nunan (1998: 61) states: tasks and exercises for developing speaking skills should be referenced against the purposes for which learners ultimately require the language. It means that whatever the tasks or exercises given by language teachers, the tasks or exercises should be focusing on the achievement of the pre-determined purposes, namely speaking skills. In other words, the tasks and exercises must have validity (Ur, 1996: 21-23) which means that the tasks or exercises should activate learners primarily in the skill or material it purposes to practice. Therefore, according to her, language teachers have to create effective language practices which can be done through the teachers' paying attention to the principles ofprelearning, volume, success-orientation, heterogeneity, teacher assistance, and interest.

Before learning or in pre-learning stage, the learners should have a good preliminary grasp of the language they are required to practice. Then, in teaching (especially speaking skills), the volume principle must also be applied, i.e., the activity should contain as much "volume" of language as possible. Success-orientation is another principle to be considered. Therefore, practice 
activities should be selected, designed, and administered in such a way that learners are likely to succeed in doing the task. Heterogeneityis another principle to consider. It means that the activity conducted by the language teacher provides opportunities to be useful to all, or most, of the different levels within a class. Another principle is that of teacher assistance. The teacher assistancecan be in the forms of the teacher's proposing an activity, giving clear instructions, and helping the learners to do the activity successfully. The lastprinciple is interestwhich means that the activities are made interesting by providing an interesting topic, the need to convey meaningful information, a game-like "fun" task, attention catching materials, appeal to learners' feelings or a challenge to their intellect.

Brown (1994) suggests that in task-based teaching, a classroom is organized around those practical tasks that language users engage in "out there" in the real world. Skehan in Beglar and Hunt (2002: 100) supports "a task is an activity in which meaning is primary, there is a communication problem to solve, and the task is closely related to real world activities."

In the previous part, several characteristics of task-basedlanguage teaching were mentioned. How it solves the problem of speaking can be illustrated by discussing its advantages. As previously mentioned, Nunan (1991a) proposes five characteristics of a task-basedteaching as follow: an emphasis on learning to communicate through interaction in the target language, the introduction of authentic texts into the learning situation, the provision of opportunities for learners to focus, not only on language, but also on the learning process itself, an enhancement of the learner's own personal experiences as important contributing elements to classroom learning, and an attempt to link classroom language learning with language activation outside the classroom. According to Ur (1996), advantages of task-based teaching language learning over other approaches are that students are likely to be more motivated if they see an activity as meaningful and as having some relevance to authentic activities which they may be called on to perform outside class. Moreover, according to Harmer (200?: 71-72) the task-based teaching "makes the performance of meaningful tasks central to the learning process...if students are focused on the completion of a task, they are just as likely to learn language as they are focusing on language forms".

Then, Thornbury (1999: 134) states that by offering learners an opportunity to make meanings for themselves, task-based approach seems to replicate more closely natural acquisition approaches.

The first characteristic is an emphasis on learning to communicate through interaction in the target language. This way the language learners will get experience on how to communicate by using the new language they are learning. It is a fact that many language learners feel bored and unenthusiastic in learning a foreign language because the language learning process that they encounter is not as they expect. However, if they find the teaching learning process meets their needs, these feelings can be avoided. Task-based teaching will overcome those feelings, which in turn, will the students' problems in speaking in the new language.

The introduction of authentic texts into the learning situation is the second characteristic that this approach has. Since the language learners think that the materials or the texts provided for them are the ones that are needed in their daily 
lives, they will do the tasks assigned to them seriously so that if they meet the same situations or problems in their daily lives, they will be able to solve them.

The third characteristic is that the provision of opportunities for learners to focus, not only on language, but also on the learning process itself. Task-based teaching will give the students opportunities to realize that they must do the process of learning the new language if they want to be able to communicate in the language. Thus, they must use the opportunities provided by their English language teacher during the teaching learning process as good as possible. By following the process, they will be better good language learners since they use the language being learned unconsciously. The process will help them overcome the problems of speaking English since they have got used to solve them in their own classroom.

The fourth characteristic is that the students will get an enhancement of their own personal experiences as important contributing elements to classroom learning. Since the students are assigned tasks to do things just like in their daily lives, their personal experiences in using the new language will be enhanced. Thus, they will know what to do and to say if they encounter the same problems as those have been assigned by their English teacher during the teaching and learning process in the classroom.

The next characteristic of it is that it has an attempt to link classroom language learning with language activation outside the classroom. By assigning the language learners some tasks that they can encounter outside of the classrooms, automatically they must activate the language that they have learned previously.Benson (2001: 143) states "learner development activities should not be separated from language learning activities". In other words, the language learning activities that the language learners are engaged in should be in line with their age level and ability. If not they will feel frustrated and get bored easily. Therefore, "the task must involve a level challenge that is suited to their perceived capacity so that their skills are put to an appropriate test" (McInerney and McInerney, 1998: 174). Ur (1996: 123-124) explains that "a task is essentially goal-oriented". To reach a goal or an objective which is usually expressed by an observable result, such as brief lists or notes, a spoken summary, a drawing, a rearrangement of jumbled items, the participants either a group or pair should do interaction to reach a consensus or to find out others' opinion. If there is some kind of visual focus to base the talking on, a task is often enhanced.

Learning a foreign language can be a frustrating experience for language learners if teaching learning process happening in the classroom are not interesting, motivating and/or meaningful to them. Skehan in Rubin and McCoy (2008) points out that a language task is meaningful in its own right and linked to the real world, although it may also be focused on a particular language goal. Task-based learning (sometimes referred to a taskbased instruction, or TBI), according to Harmer (200?: 71-72) "makes the performance of meaningful tasks central to the learning process...if students are focused on the completion of a task, they are just as likely to learn language as they are focusing on language forms." Thornbury (1999: 134) states that by offering learners an opportunity to make meanings for themselves, task-based approach seems to replicate more closely natural acquisition approaches. In line with them, Long in Nation and Newton (2009: 98) claims

...tasks that stimulate negotiation for meaning may turn out to be one 
among several useful languagelearning situations, in or out of classrooms, for they may be one of the easiest ways to facilitate a learner's focus on form without losing sight of a lesson's (or conversation's) predominant focus on meaning.

Task-based language teaching begins with as a series of tasks which are intended to develop learners' communicative skills and contribute incidentally to their language development (Ellis, 1997). More specifically, Willis in Harmer (200?: 7172) suggest three basic stages of Taskbased learning, namely "the Pre-task, the Task cycle, and the Language focus". In the first stage, the teacher helps the students understand the task instructions, explores the topic to be learnt with the classes, and highlights useful words and phrases. In the second stage, the teacher monitors the students' performing the task in small groups or pairs. Furthermore, the students plan how to tell the rest of the class about what they did and how it ended. Next, they report on the task either orally or in writing and/or compare notes on what has happened. In the last stage, the students are assigned to examine and discuss specific features of any listening or reading text that they have looked at for the task. In this stage, it is also possible for the teacher to conduct some form of practice of specific language features which the task has provoked.

In order to maximize speaking opportunities and increase the chances that learners will experience autonomous language use, there are several criteria for speaking tasks proposed by Thornbury (2006), namely, productivity (a speaking activity needs to be maximally language productive), purposefulness (a speaking activity has a clear outcome, especially one which requires learners, to work together to achieve a common purpose), interactivity (speaking activities should require learners to take into account the effect they are having on their audience, challenge (the task should stretch the learners so that they are forced to draw on their available communicative resources to achieve the outcome), safety (the classroom should provide the right conditions for experimentation, including a supportive classroom dynamic and a non- judgmental attitude to error on the part of the teacher, and authenticity (speaking tasks should have relation to real-life language use). Thus, the language learners will use the language they are learning inside or outside of the classroom based on the tasks assigned. In other words, the language learners will continuously participate in the language tasks designed by the language teacher. Harmer (2001) points out that there are three areas of teacher's behavior which can directly influence students' continuing participation. They are goals and goal setting, learning environment, and interesting classes. Interesting classes, especially, will make the students intrinsically motivated if they are interested both in the subject they are studying and in the activities and topics they are presented with. Harmer (1998: 5) points out that students are much more likely to remain interested if there are a number of different tasks with a selection of different topics.

\section{CONCLUSION}

Tasks-Based Language Teaching is appropriate to overcome the problems of speaking in a language classroom. Therefore, the language teachers should try to design the tasks that will meet their students' needs in their daily lives. Through the tasks assigned, the students will get motivated to use the language being learned inside or outside of the 
classroom. As a result, the students' speaking skills will improve. On the other hand, their speaking problems will be minimized.

\section{BIBLIOGRAPHY}

Beglar and Hunt. (2002). "Implementing Task-Based Language Teaching" in Methodology in Language Teaching: An Anthology of Current Practice. Cambridge: Cambridge University Press.

Benson, Phil. (2001). Teaching and Researching Autonomy in Language Learning. Essex: Pearon Education Limited.

Brown, H. Douglas. (1994). Teaching by Principles: An Interactive Approach to Language Pedagogy. New Jersey: Prentice Hall Regents.

Ellis, Rod. (1997). SLA Research and Language Teaching. Oxford: Oxford University Press.

Harmer, Jeremy. (1998). How to Teach English. Essex: Addison Wesley Longman Limited. . (2001). The Practice of English Language Teaching (Third Edition). London: Pearson Education Limited.
(200). The Practice of English Language Teaching (Fourth Edition). London: Pearson Education Limited.

McInerney, Dennis. M dan McInerney, Valentina. (1998). Educational Psychology (sedond editition). Singapore: Prentice Hall

Nunan, David. (1991a). "Communicative tasks and the language curriculum." Tesol Quarterly 25 (2), 279-295.

. (1998). Language Teaching Methodology: A Textbook for Teachers. Prentice Hall

Rubin, Joan, and McCoy, Patricia. (2008). "Tasks and Good Language Learners" in Griffith, Carol (Ed). Lessons from Good Language Learners. Cambridge: Cambridge University Press.

Thornbury, Scott. (1999). How to Teach Grammar. Essex: Pearson Education Limited. (2006). How to Teach Speaking. New York: Longman.

Ur, Penny. (1996). A Course in Language Teaching: Practice and Theory. Cambridge: Cambridge University Press. 